\title{
PRICE INTERDEPENDENCE OF AGRICULTURAL COMMODITIES FROM UKRAINE AND WORLD MARKETS
}

\author{
Olga Bodnar1, Julia Galchynska², Mariusz Maciejczak ${ }^{3 凶}$ \\ ${ }^{1}$ Institute of Agrarian Economics - National Research Center, Ukraine \\ ${ }^{2}$ National University of Life and Environmental Sciences of Ukraine, Ukraine \\ ${ }^{3}$ Warsaw University of Life Sciences - SGGW, Poland
}

\begin{abstract}
The objective of the paper is to present the price interdependencies between agricultural commodity products from Ukraine (both export and non-export oriented) and other commodities whose prices are shaped on world markets, with a special focus on the role of their volatility. The research demonstrates a tight connection between the global prices of crude oil and prices of Ukrainian corn and wheat. Additionally, the volatility of world prices of agricultural commodities influenced the Ukrainian national market and had significant impact on domestic price declines. At the same time, the mechanisms for pricing non-export related agricultural commodities are formed mostly under the influence of factors from the domestic market. It is argued that a low interdependency between non-export oriented agricultural commodities and world markets stipulates the social stability of Ukraine's population.
\end{abstract}

Key words: price interdependencies, agricultural commodities, financialization, Ukraine

JEL codes: L11, L16

\section{INTRODUCTION}

Agricultural commodity prices on the market are subject to constant changes, which have significantly speeded up in recent years. A common characteristic provided e.g. by Gilbert [2010] is that the overall prices for agricultural products are increasing and fluctuate significantly. Having in mind that the market for agricultural commodities has a global scope, price volatility takes place both in developed and developing countries. One such developing country, and of special importance, is Ukraine. On the one hand, the country belongs to a risky agricultural region with high dependence on agricultural production; on the other hand, as one of the world's biggest producers of agricultural commodities, it is under the influence of global market processes, especially price volatility.

Ukraine transformed into a free market economy three decades ago. The transformation processes that have taken place in agriculture and the food sector have been driven by the development of new institutions, the creation of an institutional structure for agricultural markets and the adaptation of the players to free market conditions [Zinchuk et al. 2017]. In a new situation, agriculture has become one of the driving sectors of the Ukrainian economy. According to the State Statistics Service of Ukraine [Derzhavna sluzhba statystyky Ukrayiny 2018], in just the last decade, the agricultural sector has contributed $10-12 \%$ to Ukrainian GDP. It is also worth mentioning that in the 
period 2010-2017 the share of agricultural products in total export increased from $21 \%$ in 2010 to $44 \%$ in 2017, while share of agricultural products in total imports fluctuated around $10 \%$. Agricultural exports have been the largest export category for Ukraine since 2013. In 2017, its share was almost two times bigger than that of the second largest export category (ferrous and non-ferrous metals). Tight connection with the world market of agricultural commodities has also impacted pricing mechanisms.

Modern market challenges are reflected in the excessive volatility of domestic market prices; dependence on global market prices combined with a decrease in government price control requires further research, especially regarding crop price mechanisms in Ukraine's agricultural sector. It is thus important to understand existing research on crop pricing, and to keep in mind that crops provide not only consumer products, but also resources to deliver products of animal origin as well as raw material for other sectors of the national economy. This emphasizes the importance of the crop pricing mechanism in Ukraine, especially with regard to price interdependencies.

Thus, the objective of the paper is to present the price interdependencies of agricultural commodity products from Ukraine (both export and non-export oriented) with other agricultural and non-agricultural commodities, whose prices are shaped on global markets, with a special focus on the role of their volatility.

\section{THEORETICAL BACKGROUND}

Gardebroek et al. [2014] argue that the other signum temporis (sign of the times) characteristics of agricultural commodity prices are their volatility and interactions across markets. The volatility for farmers means that their market diversification strategies will report a drop in effectiveness and a rise in costs of risk mitigation. The roots of such situations can be found not only in classical economic theories of market functioning [Gilbert and Morgan 2010] but also in theories of trade [Anderson and Nelgen 2012].

The theory of industrial organisation points out another reason, which is financing of the economy, also with regard to agricultural markets [Ménard and
Valceschini 2005]. Today, financial markets are no longer the only place where cash financing occurs. A promised land for financing is the investment in agriculture. According to Franc-Dąbrowska and Bereżnicka [2018], financing in agriculture has three forms: investment in agricultural land, increase in investment in goods and raw materials, including agricultural raw materials, and - increase in the level of farm debt. As concluded by Hamulczuk et al. [2012], one developed process is the financing of agricultural commodity markets. The financing (known also as financialization) is a process of shifting the centre of gravity of the economy from the sphere of production to the sphere of finance. Fernandez and Morley [2015] added that due to financing of agricultural markets there are observed also effects of commodity price volatility and further, the increased price volatility is translated into higher risk mitigation costs for farmers. As a consequence of the financialization of agricultural commodity markets, volatility spillovers can decrease the effectiveness of options for diversification in financial markets when agricultural and energy prices present any degree of price co-movement [Guhathakurta et al. 2020]. As indicated by Franc-Dąbrowska [2019], financialization has different perspectives and can be interpreted in different ways. Through financialization investors are able to obtain financial benefits from financial operations. From another perspective, financialization also creates an additional value that is transferred to commodity markets, especially in raw materials and agricultural products (purchased directly from farmers), and land (agricultural land in particular).

Financialization can impact markets in many ways. Recent studies show tight connections between the prices of crude oil and the prices of agricultural commodities, especially wheat, soy or corn. Gokmenoglu et al. [2020] suggested that it is oil prices that impact the price of agricultural commodities and that this process can work in both directions. Another finding can be found in research done by Czech et al. [2019], who argue that changes in oil prices influence wheat price changes, however, not vice versa. It was found that when oil prices decrease, there is an increase in the prices wheat. Accordingly, 
while analysing the interrelations between prices in food and energy markets, one needs to pay special attention on the impact of biofuels. Kong et al. [2012] showed that biofuel production as an alternative to expensive fossil fuels increased the competitiveness on the agricultural markets. According to these authors, grain commodities face competition from the demand for biofuels. They also show that the price of grains from which the biofuels are produced influences the volatility in the price of crude oil. A contrary opinion, based on empirical evidences, is given by Fernandez-Perez et al. [2016], who argue that crude oil prices have direct impact on the prices of agricultural commodities for energy purposes, but that there is no case in opposite direction. That indicates that there are both contemporaneous and long-term interactions among fuel, biofuels and agricultural commodities, with different directions of influence. These directions can be impacted by many market and non-market factors. Some of the most important factors are investments [Du et al. 2011], the exchange rate or interest rate [Chiou-Wei et al. 2019], as well as policy issues [Hamulczuk et al. 2019b].

Ukraine, being distinct from countries which have had no fundamental changes in social economic relationships, has the experience of transforming its agricultural commodity pricing mechanisms, including for crops, during a relatively small period of time. There have only been a few such transformations in the 20th century. The foundation of pricing mechanisms under the conditions of free market relationships existed in Ukraine before 1917 [Lukinov 1964]. Next came a period of planned administrative economy from 1920 to 1990 , where there was a system of centrally planned market relationships [Kutsmus et al. 2017]. In this period, the agrarian transformations caused asymmetric development of Ukrainian agriculture, most notably due to a striking discrepancy between the results of economic reforms and the assumed goals of those reforms. Prices were adjusted artificially to the needs of society with the primary objective of ensuring food security.

Under the free market economy conditions that were implemented when the country regained independence from the Soviet Union, the problem of price correlation and the impact from world markets arose. Several agricultural economists analysed the price volatility of Ukraine's agricultural commodities from different perspectives. Those scholars indicate a high dependence of price volatility from the formation and development of market institutions and relations [Shpychak et al. 2000], peculiarities in forming an offer from crop markets under the conditions of world price volatility [Varchenko et al. 2017], and an issue of price integrity while trading crops [Dem'yanenko and Nemchenko 2014]. Special attention was paid to the correlation between profit at agricultural enterprises and the price environment of the global agriculture market. Several studies [Shkvarchuk 2010, Shubravs'ka and Prokopenko 2011, Paskhaver 2016] showed high price dependencies on the dynamics of agricultural market development through the lens of international tendencies.

At the present stage in Ukraine, the features of crop production pricing consist of differentiation of crops according to export orientation [OECD 2019]. For today, the volume of exports represent crops and their products from wheat $(35 \%)$, corn $(54 \%)$, sunflower-seed oil $(90 \%)$, soy $(54 \%)$, rape seed $(99 \%)$. Additionally, as a way to ensure food security, today plant products are also considered to be a type of power resource [Shpychak et al. 2017]. Hamulczuk et al. [2019b] showed that Ukraine is a price maker in the energy crop market (i.e. rapeseed) and that the change in prices on the global market are directly transmitted into the fluctuations of local agricultural commodity prices. However, the reverse situation is also likely to happen. Hamulczuk et al. [2019a] also indicated that the increase in bioethanol production along with other market fluctuations such as low inventory, tightens the connection between Ukrainian grain prices and global crude oil prices.

\section{MATERIAL AND METHODS}

There is a systematic approach to identify the primary causes of pricing dynamics for domestic export oriented and non-export oriented crop production. Thus, the objective of the paper was to present the price interdependencies between agricultural commodity products from Ukraine (both export and non-export oriented) and other non-agricultural and agricultural 
commodities whose prices are shaped on global markets, with a special focus on the role of their volatility. The research attests to the closely coupled connections between the global prices of crude oil and prices of Ukrainian commodity products.

For above-stated purpose, retrospective analysis was used to systematize the features of pricing for crop production. The monographic method was used to present the theoretical background of the process of financialization. The research contains crops price elasticity of traditional fuel prices in the global market. The connection between prices of traditional energy resources and potential energy crops was shown. Data for prices of analysed commodities was collected from the State Statistics Service of Ukraine (Derzhavna sluzhba statystyky Ukrayiny), Food and Agriculture Organization of the United Nations and the World Bank. The analyses period covered years 2013-2017. The approach presented by Cameron and Trivedi [2005] was applied in the analysis. The Shapiro-Wilk normality test for joint distribution was also performed. Pearson's correlation and linear regression methods were used to assess the interdependence of prices for crop products in the global and domestic markets. Price elasticity was computed in Excel using the XLSTAT statistical software.

\section{RESEARCH RESULTS AND DISCUSSION}

The dependencies that arise from world prices on export oriented types of crops were analysed. In particular, a cross-correlation analysis was conducted on the basis of annual values for prices of wheat, corn, soy oil and crude oil on world markets, in the course of which the performance indicators were prices on corresponding types of plant products $\left(Y_{n}\right)$ (soy oil, corn, wheat), and factor points were prices on crude oil $(X)$. The results are presented in Table 1.

The research shows a very tight connection between the prices of crude oil and prices of corn (correlation coefficient 0.90) and costs of wheat (correlation coefficient 0.92 ). It shows high values of elasticity rates in term of price changes from 2005 to 2017 . At a price change of crude oil by $1 \%$, prices on corn change by $0.9 \%$, on wheat accordingly by $0.76 \%$. In addition, the level of connection between the prices of crude oil and soy oil was investigated. Here the coefficient of correlation was 0.89 , which shows closely coupled connections. Thus, price changes of crude oil by $1 \%$ stipulate price changes on soy oil by $0.84 \%$.

That the volatility of world prices influenced the national market unfortunately was shown by the internal price declines. It was clearly traced on the market of corn $(2013 / 2014,2014 / 2015$, in the first half of 2017/2018) that is presented in Figure 1. In this case it needs to be stated that the effective internal mechanisms of governmental price control, insurance against price vibrations, possibilities of prognostication of prices on internal and world markets are absent on the internal market of export oriented crops. In conditions of price instability on the world market and its corrections, traders include price risks in the margin that forms the difference between internal and export prices. At the starting point is the export price, but all price risks are levelled due to reductions of the purchase price from a direct producer.

Table 1. Cross-correlation dependence between prices of traditional types of fuel and prices of separate types of crop products in the world markets in 2015-2017

\begin{tabular}{lcccc}
\hline Type of crop & $\begin{array}{c}\text { Correlation } \\
\text { coefficient }\end{array}$ & $\begin{array}{c}\text { Determination } \\
\text { coefficient }\end{array}$ & $\begin{array}{c}\text { Elasticity } \\
\text { coefficient }\end{array}$ & Regression equation \\
\hline Soya oil & 0.89 & 0.78 & 0.84 & $Y=308.9176+8.1269 X$ \\
\hline Corn & 0.90 & 0.82 & 0.90 & $Y=64.95776+1.7398 X$ \\
\hline Wheat & 0.92 & 0.85 & 0.76 & $Y=85.8306+2.1998 X$ \\
\hline
\end{tabular}

$X$ - price of crude oil, $Y_{n}$ - prices of corresponding types of crop products.

Sources: Authors' own investigation based on data from the World Bank (World Bank commodities price data, the Pink Sheets). 
Bodnar, O., Galchynska, J., Maciejczak, M. (2020). Price interdependence of agricultural commodities from Ukraine and world markets. Acta Sci. Pol. Oeconomia 19 (4), 15-22, DOI: 10.22630/ASPE.2020.19.4.36

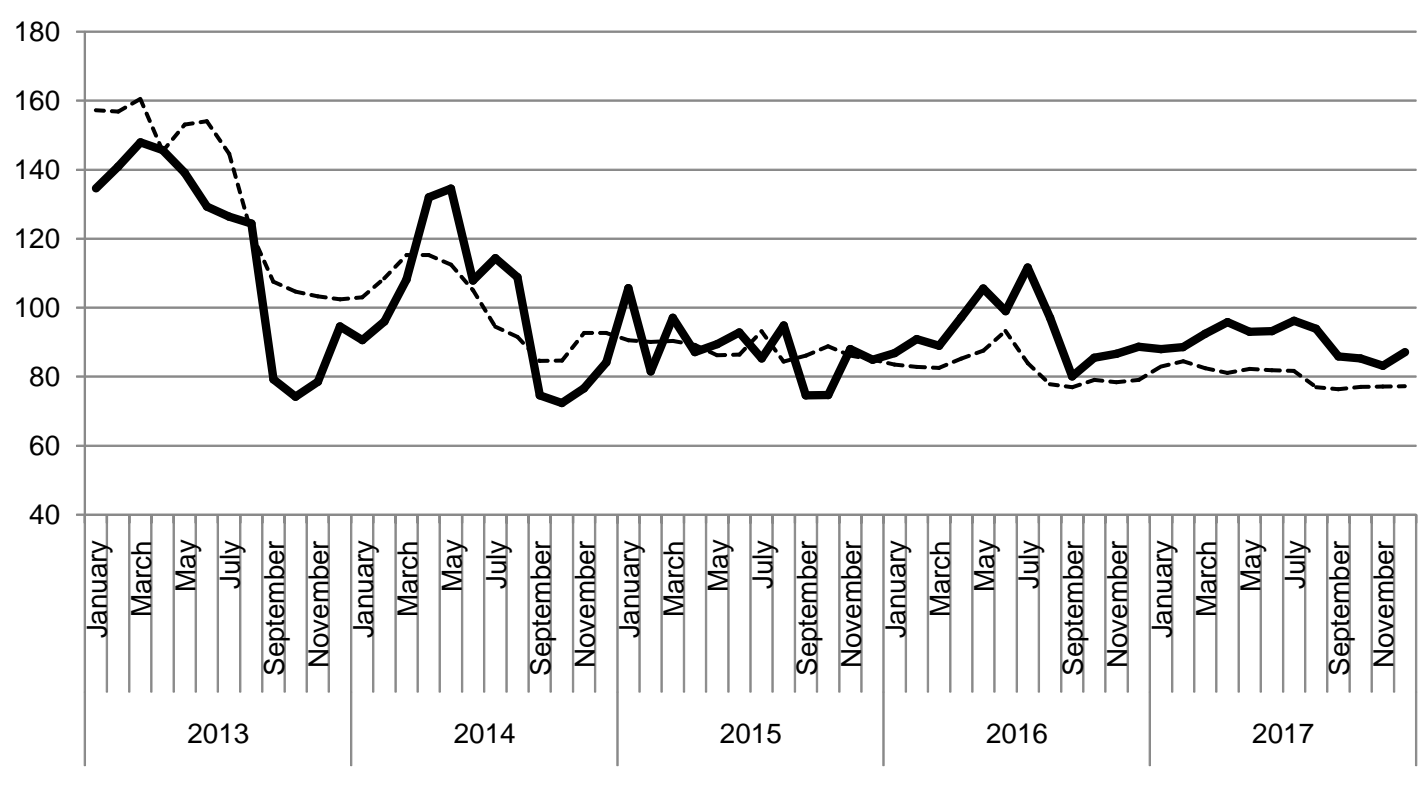

----- World Market Price Index (FOB Mexican Gulf),\%

Ukrainian Agricultural Producers Price Index,\%

Fig. 1. Interdependence of world and internal prices on the example of corn in 2013-2017 (2014=100\%) Sources: Authors' own investigation based on data from the State Statistics Service of Ukraine and the World Bank.

Today, the process of forming internal prices on the home markets of export oriented types of crop products takes place according to the following sequence: orientation to the standard of prices on large exchanges of the world - making export contracts with the indicated cost of delivery, cost settling of products purchased on the internal market for its direct producer with the deduction of logistic charges related to transportation of commodities to port elevators or other setting points. On the basis of the conducted cross-correlation analysis, high enough dependence of internal prices is induced on export oriented types of crop products from the price situation on the world market (coefficient of correlation $0.78-0.80$ depending on the type of product). The induced dependencies are presented in Table 2.

Table 2. Cross-correlation dependence between prices on export oriented types of crops on internal and world markets in 2013-2017

\begin{tabular}{lccc}
\hline Type of crop & $\begin{array}{c}\text { Correlation } \\
\text { coefficient }\end{array}$ & $\begin{array}{c}\text { Determination } \\
\text { coefficient }\end{array}$ & Regression equation \\
\hline Corn & 0.78 & 0.60 & $Y=51.3891+0.6316 X$ \\
\hline Wheat & 0.79 & 0.63 & $Y=50.7442+0.50763 X$ \\
\hline Barley & 0.80 & 0.64 & $Y=21.3499+0.93471 X$ \\
\hline Sunflower & 0.78 & 0.61 & $Y=12.11400+0.34708 X$ \\
\hline Soya beans & 0.78 & 0.61 & $Y=144.59469+0.7136 X$ \\
\hline
\end{tabular}

$X$ - price at world exchanges on the corresponding type of crop, $Y_{n}$ - prices on the internal market for the corresponding type of crop.

Sources: Authors' own investigation based on data from the State Statistics Service of Ukraine. 
Analysis was also conducted focusing on the dependencies that arise from world prices on nonexport oriented types of crops. The non-export oriented types of crops (potato, vegetables, garden-stuffs and other) are used mainly for domestic consumption, largely out of commodity-money relations (potato $-76 \%$, vegetables $-42 \%$ ). Their export volume represents up to $12 \%$ of production volume depending on the commodity. These types of products are grown mainly in small family farms (80-98\% depending on the commodity). The mechanism of pricing on these products is formed mostly under the influence of factors from the internal market (Fig. 2).

During the analyzed period, where high rates of inflationary and dilutive processes (as in 2014-2015) resulted in the decline in profit levels for the Ukrainian population, the non-export oriented types of products secured food availability for the rural population. It is especially observed with regard to the retail price of potatoes, which did not have considerable rates of increase, while the index of the share of consumed potatoes of self-production increased.

\section{CONCLUSIONS}

One can argue that there is a price dependence between export oriented agricultural products from Ukraine (such as corn, wheat, barley, sunflower seeds and sunflower oil, crude, soy) and the price situation of such products on the world market. This happens due to demand levels on the world market and extend to the export volume of these crops from Ukraine. In the case of favorable market conditions, they provide a major cash flow for producers. Such a situation has lent itself to a considerable investment in agriculture and is one of the reasons to concentrate on these types of products. In order to decrease the dependence of domestic market prices on export oriented crops and the volatility of world prices, there needs to be diversification of product usage to encompass alternative uses, including industrial. These products may be used in flour, in the oil and fat industry or for feeding on milk, beef or pork farms. Ukrainian farmers and industrial enterprises need to find their own new places in the world market. Additionally, a low interdependency

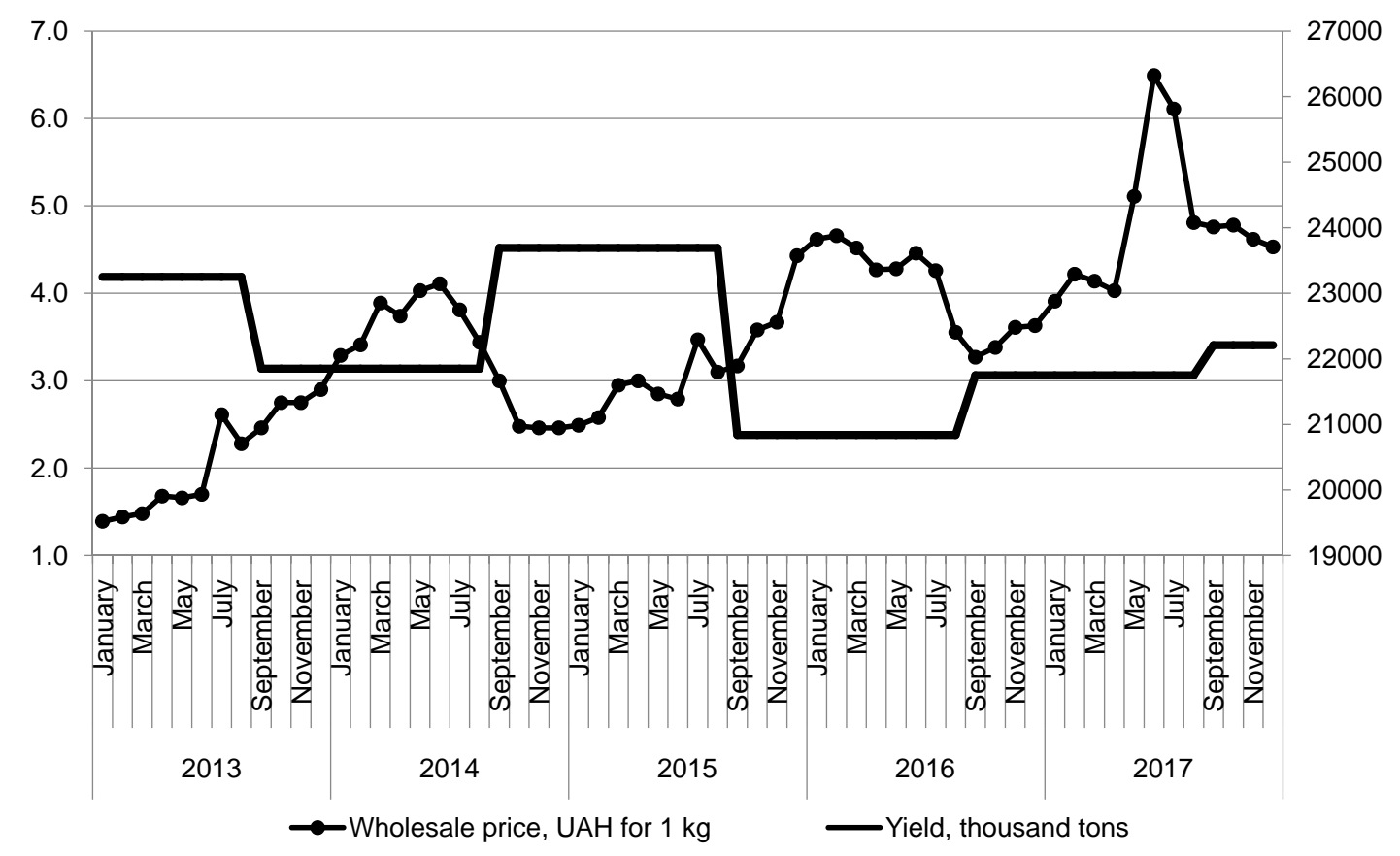

Fig. 2. Dependence between the dynamics of prices on the potato market and volume of its gross harvest in Ukraine in 2013-2017

Sources: Authors' own investigation based on data from State Statistics Service of Ukraine. 
between non-export oriented agricultural commodities and the world market can give a special avenue for social stability of the Ukrainian population and should therefore be a subject of state policy.

\section{REFERENCES}

Anderson, K., Nelgen, S. (2012). Trade Barrier Volatility and Agricultural Price Stabilization. World Development, 40 (1), 36-48.

Cameron, C., Trivedi, P. (2005). Microeconometrics. Methods and Applications. Cambridge University Press, Cambridge.

Chiou-Wei, S-Z., Chen, S-H., Zhu, Z. (2019). Energy and agricultural commodity markets interaction: an analysis of crude oil, natural gas, corn, soybean, and ethanol prices. The Energy Journal, 40 (2), 265-296.

Czech, K., Górska, A., Kozioł-Kaczorek, D. (2019). Związki cenowe towarów w warunkach finansjeryzacji gospodarki na przykładzie cen ropy naftowej, złota i pszenicy [Price relations of goods in the conditions of financialisation of the economy on the example of oil, gold and wheat prices]. Wydawnictwo SGGW, Warszawa.

Dem'yanenko, S., Nemchenko, H. (2014). Tsinova intehratsiya pry torhivli sil's'kohospodars'koyu produktsiyeyu [Price integration in trade in agricultural products]. Monitorynh Birzhovoho Rynku - Stock Market Monitoring, 3 (22), 16-19.

Derzhavna sluzhba statystyky Ukrayiny [State Statistics Service of Ukraine] (2018). Sil's'ke hospodarstvo Ukrayiny. Statystychnyy zbirnyk 2017 [Agriculture of Ukraine. Statistical Yearbook 2017]. Kyiv.

Du, X., Cindy, L.Y., Hayes, D.J. (2011). Speculation and volatility spillover in the crude oil and agricultural commodity markets: A Bayesian analysis. Energy Economics, 33 (3), 497-503.

Fernandez, J.M., Morley, B. (2015). Interdependence among Agricultural Commodity Markets, Macroeconomic Factors, Crude Oil and Commodity Index. Bath Economics Research Working Papers, 42/15, 65-76.

Fernandez-Perez, A., Frijns, B., Tourani-Rad, A. (2016). Contemporaneous interactions among fuel, biofuel and agricultural commodities. Energy Economics, 58, 1-10.

Franc-Dąbrowska, J. (2019). Financialization and speculation in agriculture - positive and negative aspects of the financialization of the economy. Annals Polish Association of Agricultural and Agribusiness, 21 (3), 73-81.

Franc-Dąbrowska, J., Bereżnicka, J. (2018). Ufinansowienie gospodarki a zakres i skala zadłużenia gospodarstw rolniczych [Financialization of the Economy vs. the Scope and Scale of Agricultural Farms]. Prace Naukowe Uniwersytetu Ekonomicznego we Wrocławiu [Research Papers of Wrocław University of Economics] 533. Finanse przedsiębiorstw i gospodarstw rolnych [Finances of enterprises and agricultural farms], 73-82.

Gardebroek, C., Hernandez, M., Robles, M. (2014). Market interdependence and volatility transmission among major crops. IFPRI Discussion Paper 01344.

Gilbert, C.L. (2010). How to understand high food prices. Agricultural Economics, 6, 398-425.

Gilbert, C.L., Morgan, C.W. (2010). Food price volatility. Philosophical Transactions of the Royal Society B, 365, 3023-3034.

Gokmenoglu, K.K., Güngör, H., Bekun, F.V. (2020). Revisiting the linkage between oil and agricultural commodity prices: Panel evidence from an Agrarian state. International Journal of Finance \& Economics, https://doi. org/10.1002/ijfe.2083

Guhathakurta, K., Dash, S.R., Maitra, D. (2020). Period specific volatility spillover based connectedness between oil and other commodity prices and their portfolio implications. Energy Economics, 85, 104566, https://doi. org/10.1016/j.eneco.2019.104566

Hamulczuk, M., Gędek, S., Klimkowski, C., Stańko, S. (2012). Prognozowanie cen surowców rolnych na podstawie zależności przyczynowych [Forecasting prices of agricultural commodities based on causal relationships]. IERiGŻ-PIB, Warszawa.

Hamulczuk, M., Makarchuk, O., Galchynska, J. (2019a). Linkage of grain prices in Ukraine with the world crude oil prices. Economic Annals-XXI, 175 (1-2), 40-44.

Hamulczuk, M., Makarchuk, O., Sica, E. (2019b). Searching for market integration: Evidence from Ukrainian and European Union rapeseed markets. Land Use Policy, 87, 104078, https://doi.org/10.1016/ j.landusepol.2019.104078

Kong, M., Han, D.B., Nayga, R.M. Jr (2012). Interrelationship and Volatility Transmission between Grain and Oil Prices. [In:] 2012 Annual Meeting, August 12-14, 2012, Seattle, WA. Agricultural and Applied Economics Association, https://www.doi.org/10.22004/ag.econ.124377

Kutsmus, N., Kovalchuk, O., Dankevych, V. (2017). Agricultural Development in Ukraine: Institutional Changes and Socio-Economical Results. Kwartalnik Naukowy Uczelni Vistula, 2 (55), 84-99.

Lukinov, I.I. (1964). Tsenoobrazovaniye i rentabel'nost' proizvodstva sel'skokhozyaystvennykh produktov [Pricing and profitability of agricultural products production]. Kolos, Moskva. 
Ménard, C., Valceschini, E. (2005). New institutions for governing the agri-food industry. European Review of Agricultural Economics, 32 (3), 421-440.

OECD (2019). Agricultural Policy Monitoring and Evaluation 2018. Paris.

Paskhaver, B.Y. (2016). Pribyl'nost' i rentabel'nost' sel'skokhozyaystvennykh predpriyatiy v inflyatsionnom protsesse [Profitability and profitability of agricultural enterprises in the inflation process]. Ekonomika i Prognozirovaniye - Economics and Forecasting, 3, 66-76.

Shkvarchuk, L.O. (2010). Mekhanizm rehulyuvannya tsin na prodovol'chomu rynku [The mechanism for price regulation in the food market]. Derzhavna ustanova NASU, Lviv.

Shpychak, O.M., Sabluk, P.T., Sytnyk, V.P., Nikolayeva, Z.P., Bilash, V.P. (2000). Tsiny, vytraty, prybutky ahrovyrobnytstva ta infrastruktura prodovol'chykh rynkiv Ukrayiny [Prices, costs, profits of agricultural production and food market infrastructure of Ukraine]. IAE, Kyiv.
Shpychak, O.M., Bodnar, O.V., Shpychak, O.O. (2017). Teoretyko-metodolohichni ta praktychni osnovy tsinoutvorennya [Theoretical, methodological and practical bases of pricing]. Komprint, Kyiv.

Shubravs'ka, O.V., Prokopenko, K.O. (2011). Rozvytok ahrarnoho rynku Ukrayiny $\mathrm{v}$ umovakh diyi innovatsiynykh chynnykiv [Development of agrarian market of Ukraine in conditions of innovative factors]. Ekonomika i Prognozirovaniye - Economics and Forecasting, 2, 118-129.

Varchenko, O.M., Svynous, I.V., Lypkan', O.V. (2017). Osoblyvosti formuvannya popytu na prodovol'stvo $\mathrm{v}$ suchasnykh umovakh [Features shaping demand for food in today's conditions]. Aktual'ni Problemy Ekonomiky - Actual Problems of the Economics, 1, 52-60.

Zinchuk, T., Kutsmus, N., Kovalchuk, O., Dankevych V., Usiuk, T. (2017). Institutional Transformation of Ukraine's Agricultural Sector. Review of Economic Perspectives, 17 (1), 57-80.

\section{WSPÓŁZALEŻNOŚCI CENOWE TOWARÓW ROLNYCH Z UKRAINY I RYNKU ŚWIATOWEGO}

\section{STRESZCZENIE}

Celem artykułu jest przedstawienie zależności cenowych towarów rolnych z Ukrainy (zarówno eksportowanych, jak i nieeksportowanych) od innych towarów, których ceny kształtują się na rynkach światowych, ze szczególnym uwzględnieniem roli ich zmienności. Badania wskazują na istnienie związku między światowymi cenami ropy naftowej a cenami ukraińskiej kukurydzy i pszenicy. Dodatkowo kształtująca rynek krajowy zmienność światowych cen surowców rolnych miała istotny wpływ na spadki cen na Ukrainie. Mechanizm cen towarów rolnych niezwiązanych z eksportem kształtuje się głównie pod wpływem czynników rynku krajowego. W związku z tym mała współzależność cen nieeksportowych towarów rolnych i cen na rynku światowym warunkuje stabilność społeczną na Ukrainie.

Słowa kluczowe: współzależności cenowe, towary rolne, finansjeryzacja, Ukraina 